\title{
Working
}

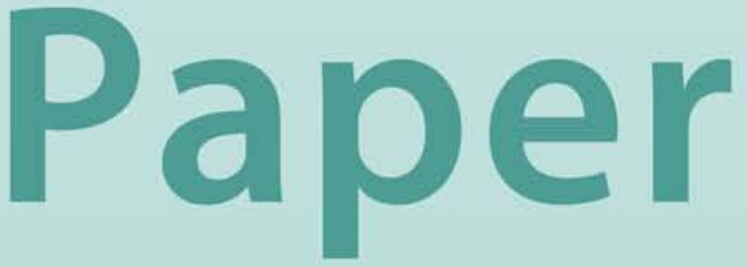




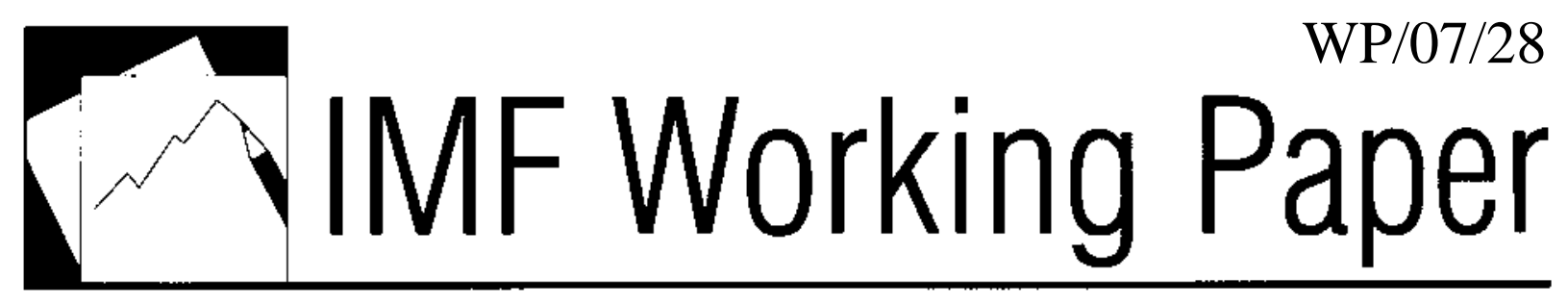

\section{Public Pension Reform: A Primer}

Alain Jousten 


\title{
IMF Working Paper
}

Fiscal Affairs Department

Public Pension Reform: A Primer

Prepared by Alain Jousten ${ }^{1}$

Authorized for distribution by Michael Keen

February 2007

\begin{abstract}

\section{This Working Paper should not be reported as representing the views of the IMF.} The views expressed in this Working Paper are those of the author(s) and do not necessarily represent those of the IMF or IMF policy. Working Papers describe research in progress by the author(s) and are published to elicit comments and to further debate.

The present paper reviews key issues in pension design and pension reform encountered all across the world. The paper heavily refers to the recent U.S. Social Security reform debate in general and to the Personal Retirement Accounts proposal in particular. A particular emphasis is put on annuitization and risk-taking in the economy. Our discussion signals some inadequacy of the proposed measures with respect to the goals of viability of the system and individual financial security during retirement.
\end{abstract}

JEL Classification Numbers: G23, H31, H53, H55, J11, J26

Keywords: household behavior, welfare programs, social security, pension funds, demographic trends, retirement

Author’s E-Mail Address: ajousten@imf.org

\footnotetext{
${ }^{1}$ This paper was written while visiting the IMF as a visiting scholar. I would like to thank the Fiscal Affairs Department of the IMF for its hospitality, and particularly Thomas Dalsgaard, Robert Gillingham, Peter Heller, Sandy Mackenzie, and Michael Keen for their helpful discussions and comments. The views expressed in this paper are entirely my own and do not reflect the opinion nor the policy of neither the IMF nor the Université de Liège, CEPR, IZA. Comments welcome at: ajousten@imf.org.
} 
I. Introduction $\underline{3}$

II. The Social Security Reform Proposal.....

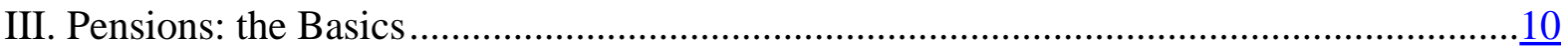

A. Longevity Risk and the Role of Annuities .....................................................

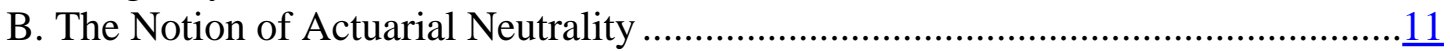

C. Defined Benefit and Defined Contribution Plans ............................................... $\frac{12}{14}$

D. PAYG and the Accounting of Public Pensions..................................................14

E. Why Public Intervention?...............................................................................

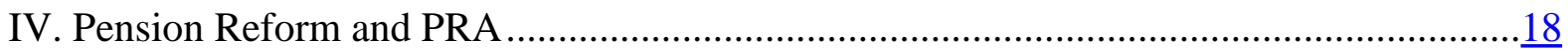

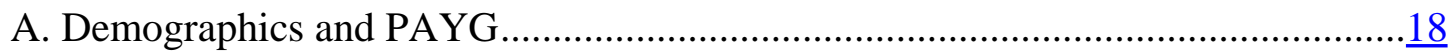

B. Individual Savings and Returns................................................................... $\frac{19}{22}$

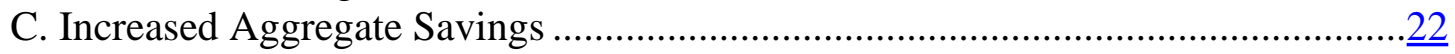

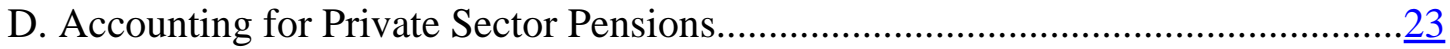

E. Accounting for Public Sector Pensions ..............................................................

V. Further Design Issues....................................................................................25

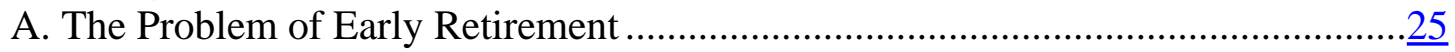

B. Economics of Guarantees......................................................................

C. Who Guarantees Private Sector Pensions?........................................................29

D. What About Inflation Risk? ........................................................................

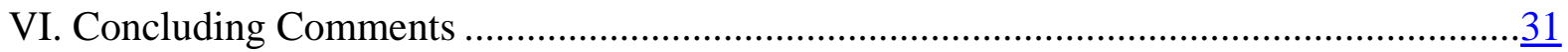

Tables

1. Total Fertility, Under Different Scenarios.

2. Life Expectancy at Birth, 2000-05 and 2045-50 ......................................................

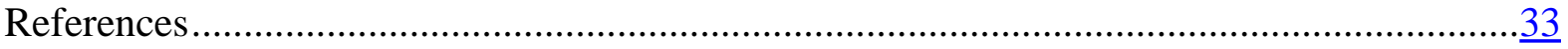




\section{INTRODUCTION}

Pension reform is a subject of hot debate all around the world. ${ }^{2}$ Over the last years, the world has witnessed a marked increase in public awareness about the need for retirement income planning. Struck by the looming financial crisis of most public retirement income programs, individuals and governments alike have started to give the retirement income issue a second look. The recommendations of public and private financial advisors generally involve some form of private retirement savings, be it at the level of the individual or the workplace. The motivation for these common recommendations lies in the considerable projected financial problems of the pay-as-you-go (PAYG) systems in the decades to come, once the baby-boomers enter retirement.

The basic demographic process is fundamentally the joint product of two different, though clearly related phenomena. It affects the population structure both at the bottom and the top. To start with the beginning of a person's life-cycle, a substantial decrease in the fertility rate has been observed in all developed countries. Though the same is not (yet) universally observable in the entire developing world, the very same fundamental process seems to be at work. In the most recent world population projections, the UN considers that even in a high fertility scenario all less developed regions would fall to a fertility level that is significantly lower than the currently observed one (see Table 1).

The reasons for a decrease in the number of childbirths per woman have to be sought at multiple levels. The onset of a slowdown in fertility rates usually goes hand in hand with strongly decreasing child mortality. In later stages of the process, other factors such as increased female labor force participation play an increasing role and lead to later childbirth as well as to increased monetary and nonmonetary costs of children.

\footnotetext{
${ }^{2}$ In the present paper, I refer to the term Social Security as the retirement portion of the U.S. Social Security program, which represents the predominant public pension system in the United States. The term social insurance is used as a short-cut for all public insurance programs such as retirement, unemployment, disability and (often) health insurance.
} 
Table 1. Total Fertility, Under Different Scenarios

\begin{tabular}{|c|c|c|c|c|c|c|}
\hline \multirow[b]{3}{*}{ Major area } & \multicolumn{6}{|c|}{ Total Fertility (Children per woman) } \\
\hline & \multirow[b]{2}{*}{$1970-75$} & \multirow[b]{2}{*}{ 2000-05 } & \multicolumn{4}{|c|}{$2045-50$} \\
\hline & & & Low & Medium & High & Constant \\
\hline World & 4.49 & 2.65 & 1.56 & 2.05 & 2.53 & 3.50 \\
\hline More developed regions & 2.12 & 1.56 & 1.34 & 1.84 & 2.34 & 1.67 \\
\hline Less developed regions & 5.44 & 2.90 & 1.59 & 2.07 & 2.56 & 3.69 \\
\hline Least developed countries & 6.61 & 5.02 & 2.08 & 2.57 & 3.05 & 5.56 \\
\hline $\begin{array}{l}\text { Other less developed } \\
\text { countries }\end{array}$ & 5.28 & 2.58 & 1.42 & 1.92 & 2.41 & 3.06 \\
\hline Africa & 6.72 & 4.97 & 2.03 & 2.52 & 3.00 & 5.50 \\
\hline Asia & 5.08 & 2.47 & 1.42 & 1.91 & 2.41 & 2.98 \\
\hline Europe & 2.16 & 1.40 & 1.33 & 1.83 & 2.33 & 1.45 \\
\hline $\begin{array}{l}\text { Latin America and the } \\
\text { Caribbean }\end{array}$ & 5.05 & 2.55 & 1.36 & 1.86 & 2.36 & 2.69 \\
\hline Northern America & 2.01 & 1.99 & 1.35 & 1.85 & 2.35 & 1.99 \\
\hline Oceania & 3.23 & 2.32 & 1.42 & 1.92 & 2.42 & 2.72 \\
\hline
\end{tabular}

Source: Population Division of the Department of Economic and Social Affairs of the United Nations Secretariat (2005); World Population Prospects: The 2004 Revision Highlights (New York: United Nations).

The second and equally important demographic factor at play is the remarkable increase in life-expectancy we have witnessed in the last decades. Though originally clearly playing at young ages, there has been a tendency towards something that is commonly referred to as the rectangularization of the survival curve, i.e., the fact that gains in life expectancy are realized all across the age spectrum. ${ }^{3}$ Table 2 summarizes the key trends for different regions of the world.

\footnotetext{
${ }^{3}$ An interesting and equally important question is to know how much of that added life-span is actually spent in good health. This question is of an utmost importance within the context of long-term care issues. Considering long-term care insurance, it is crucial to be aware not only of the projected increases in longevity but also of the time that a person would be expected to be in need of care.
} 
Table 2. Life Expectancy at Birth, 2000-05 and 2045-50

\begin{tabular}{lcc}
\hline Major area & $2000-05$ & $2045-50$ \\
\hline World & 65.4 & 75.1 \\
More developed regions & 75.6 & 82.1 \\
Less developed regions & 63.4 & 74.0 \\
$\quad$ Least developed countries & 51.0 & 66.5 \\
$\quad$ & 66.1 & 76.3 \\
Other less developed countries & 49.1 & 65.4 \\
Africa & 67.3 & 77.2 \\
Asia & 73.7 & 80.6 \\
Europe & 71.5 & 79.5 \\
Latin America and Caribbean & 77.6 & 82.7 \\
Northern America & 74.0 & 81.2 \\
Oceania & & \\
\hline
\end{tabular}

Source: Population Division of the Department of Economic and Social affairs of the United Nations Secretariat (2005); World Population Prospects: The 2004

Revision Highlights (New York: United Nations).

These two concomitant trends have a major impact on most social insurance programs around the world. In most countries, social insurance programs rely on PAYG financing not only for their retirement programs, but also frequently for their disability, health, and unemployment accident programs. In a PAYG system, the above demographic trends have a clear impact. All other things equal, as the expenditures of the system increases as the number of beneficiaries rises, there is a simultaneous decrease in the revenues and the number of people contributing to the system.

The resulting policy implications for assuring the viability of the system in the face of an aging process are equally easy to grasp. Though there is a myriad of ways that policymakers can react, all of these policies can be summarized to a simple observation of a need for benefit cuts to current and future retirees or contribution hikes for current and future workers. The most obvious, but politically rather unattractive, option would be to introduce explicit benefit cuts or contribution hikes to the system. Next to this, there are a series of other measures that achieve the same ultimate goal, such as a widening of the contributory base, or restrictions in terms of the eligibility for benefits. A commonly recommended measure, namely increasing the retirement age has the advantage of working on both sides simultaneously. 
But beyond the sheer size of the demographic problems ahead, pensions are also a topic where everybody seems to have some opinions on what a reform should do. This is maybe surprising given that many people actually lack a fundamental idea of what the current systems — as a point of departure-represent to them. Börsch-Supan and others (2005) document that among a sample of German and Italian citizens, about 50 percent believe that reforms undertaken so far were just a first step towards stabilization. 40 percent of those surveyed believed that the reforms were ineffective. At the same time, approximately 60 percent of those surveyed did not understand the PAYG basis of the respective pension systems, while a huge 80 percent did not know the contribution rate to the respective system. Similar evidence exists for other countries. ${ }^{4}$

The reasons for this situation are simple. It is a multi-factor problem with big stakes for all parties involved, be it the citizens, the government, or the corporate and financial communities. Indeed, whatever choice a country makes in terms of its pension system, it is clearly not neutral with respect to the distributional impact, but also the allocative efficiency of the economy. The distributional impact includes both intergenerational and intragenerational considerations. While the point might at first seem rather obvious, a closer look reveals rather complex shifts both in terms of income and in terms of risks across generations and within generations.

As a whole, the study of retirement behavior, as well as retirement income programs is a well-trodden area, both in the public finance and labor economics literature on the one hand, and in financial economics on the other. The general theoretical mechanisms at stake are by now well documented. On the empirical side, the research used to have a distinct U.S. focus, given the readily available data. Over the last few years, European countries have made substantial efforts to improve their datasets, both administrative and survey-based. ${ }^{5}$ As a result, a fresh wave of international and comparative research projects has emerged. A particular line of research has emphasized the retirement incentives generated by public social insurance systems as well as the impact of reforms in terms of budgets, retirement behavior and well-being (Gruber and Wise 1999, 2004, 2005).

The present primer on pensions and pension reform attempts to survey the key ingredients and factors that are inevitably touched upon in any pension debate. The paper uses selected topics from the recent U.S. Social Security reform debate as a useful real world reference. ${ }^{6}$ However, instead of pretending to give a comprehensive treatment of the reform debate, the paper deliberately relies on a selective treatment of and a special emphasis on a few topics

\footnotetext{
${ }^{4}$ See for example Schokkaert and others (2000) for the Belgian Region of Flanders.

${ }^{5}$ See for example the creation of the comprehensive Crossroads Bank for Social Security that integrates all social insurance relevant administrative data in Belgium (ksz-bcss.fgov.be) as well as the Survey of Health Aging and Retirement in Europe (www.share-project.org).

${ }^{6}$ For a more complete outline of the Bush administration 2005 reform proposal, see www.whitehouse.gov/infocus/social-security/200501/socialsecurity.pdf.
} 
that are frequently willingly or unwillingly left out of the debate. The structure of the paper mirrors this approach. The next section spells out the key aspects of the 2005 United States reform proposal with a special focus on the Personal Retirement Accounts. Section 3 positions the debate by describing the underlying justifications for the existence of pension schemes. Section 4 reviews the validity of the reform proposal focusing on some classical motivations for reform of public pension schemes. Section 5 spells out some further key design issues and draws on international and private sector experiences to address them. Section 6 concludes.

\section{The Social SEcurity Reform Proposal}

\section{A. Summary}

In February 2005, the President of the United States unveiled a reform proposal to make the Social Security system, i.e., the public social insurance based pension system, ready for the challenges of the $21^{\text {st }}$ century. Starting with a postulate of inadequacy of the current system, which has been in place since the 1930's, the proposal intends to fundamentally change the architecture of the system with an announced objective of strengthening the system. In the above-mentioned White House document, the transition is actually not discussed further. In what follows, I will thus largely rely on the original comprehensive reform plan that was proposed by Robert Pozen. ${ }^{7}$

The key features of the reform proposal can be summarized as follows. Under the proposal, the total contributions rate is maintained at the current level of 12.4 percent of taxable earnings (employer and employee portion of social security taxes). Benefit entitlements would be scaled down by two mechanisms. First, there would be a partial shift from wage-toprice indexation in the benefit formula. The measure would mostly impact on higher income earners, and thus de facto lead to a reinforcement of the implicit redistribution towards lowincome workers. Second, under the proposal a system of Personal Retirement Accounts (PRA) — a simple variant of an individual account system—-would be introduced. Workers would be entitled to divert part of their payroll taxes on a voluntary basis into the PRA. In what follows, the paper focuses on this second mechanism the effects whereof are less well understood than the former.

\section{B. PRA}

Participation in the PRA plan is a one off option granted to each worker, with no way back. Ultimately, the plan would allow individuals to divert payroll taxes of up to 4 percent to the new accounts. Maintaining a system of tax deductibility rather than savings incentives through tax credits has to be seen as a political choice in favor of higher-income individuals

\footnotetext{
${ }^{7}$ Other proposals circulate. For a review of their budgetary implications for Social Security, visit www.ssa.gov/OACT/solvency/index.html.
} 
who benefit more from tax deductibility than people in lower-income brackets because of differing marginal income tax rates.

PRA are special savings accounts, in the sense that money accumulates in them, and balances accrued can be inherited and passed on to others. They would enable people to have some influence on the investments that are made using the money in the PRA. PRA's would however not give individuals a full decision right on the use of the funds. First, the money would be locked into the account up to retirement. Second, individuals would only have a choice among a series of pre-approved low-cost and broad-based investment vehicles. Along more traditional products, the proposal aims to introduce two new products, a life-cycle portfolio that gradually shifts away from stocks into bonds as a person ages and a secure government bond fund with a guaranteed rate of return above inflation.

The PRA would be modeled on the structure of the U.S. Thrift Savings Plan (TSP). For federal government employees TSP are the equivalent to the $401(\mathrm{k})$ plans of the private sector. The main distinct features are a centralized structure for collecting contributions, reduced management and administration costs by pre-selecting a limited number of investment funds, and pre-selection of information about withdrawal strategies. ${ }^{8}$ Under the PRA, the accumulated pension savings could be withdrawn in a variety of ways on or after retirement. Annuity purchases and phased withdrawal plans are one broad class of options, lump-sum withdrawals is the other one. ${ }^{9}$ The latter option would only be admissible if the person does not drop below the income poverty line, i.e., if he has sufficient other periodic incomes to assure he stays above the mentioned limit.

The system would also contain a grandfathering rule, making sure that the system does not change benefits promised for those born before 1950. The economic reasoning behind this grandfathering rule is simple. People have planned according to a given set of rules. Given their relatively high age (above 55), they do not have a sufficiently long horizon over which they could readjust to the reform, notably by optimally readapting their labor supply and savings behavior. Hence, any absence of grandfathering would de facto be economically equivalent to a lump-sum tax on them. Similarly, benefit changes for younger cohorts would have to be phased in progressively, for the very same reason.

The reform would necessitate major government borrowing during a prolonged transition period to offset the reduced contributions to Social Security. The magnitude and duration of this transitory borrowing would be a function of the number of people subscribing to the new PRA arrangement. The reason for this additional government borrowing is due to the timing mismatch between costs and benefits of the reform for the public finances. The current Social Security system is predominantly organized along the PAYG principle, whereas the new PRA is essentially a private funded retirement savings vehicle. Public finances thus suffer

\footnotetext{
${ }^{8}$ In line with IRA and 401(k) rules, limited withdrawals are possible before retirement.

${ }^{9}$ See Reno and others (2005) for a detailed discussion of issues relating to annuitization, such as survivor, spousal and other dependent benefits.
} 
from an immediate income loss due to lower payroll tax revenue as soon as the first person opts out of the system. The benefits to the public budgets are the lowered future expenses resulting from a reduction in Social Security benefit payouts as a result of the individuals' choice for the PRA savings accounts.

These future claims of the public sector can take two different forms. The first and most important one would come from an offset against Social Security retirement and aged survivor benefits for those who participate in the PRA. ${ }^{10}$ The offset an individual would face would be computed in three steps. A hypothetical benefit entitlement would be determined based on the workers earnings history as if he had not participated in the PRA scheme. Then, the PRA contributions (including inherited ones) would be discounted to the age of retirement using a real-beyond consumer price inflation-discount rate of 3 percent to form the fictive present discounted value of the PRA. It is important to stress that this present discounted value is completely independent of the actually observed balance in the account, which might be higher, but also lower than the above fictive amount. The fictive amount is then finally converted into a fictive annuity payout stream, the offset amount, which again relies on a 3 percent real interest rate, and on up-to-date life tables. The offset amount represents the sum that is subtracted from a PRA participant's monthly Social Security benefit as a consequence of the person's participation in the PRA, and thus represents lower future public expenditures. On the individual level, it is economically equivalent to the reimbursement of a fixed-rate loan that would have been contracted to do PRA savings. As such, the PRA does not affect the individual's (minimum) benefit entitlements under Social Security rules, but rather affects the disposable income of the individual once the PRApayouts minus the offset have been taken into account.

The second public income source helping to finance the transition is a similar mechanism which kicks in when an individual dies before retiring. The original Pozen plan includes such a provision for single individuals who die before retirement, but the administration seems not to plan to go down this route. In this case, the balance of the PRA would be reduced by a similarly computed present discounted value to compensate for the earlier deviation of part of the payroll taxes to the PRA. Hence, the net amount a single individual will be able to bequeath will be the difference between the accumulated PRA balance and the PDV of contributions diverted from the Social Security system.

Absent a fully symmetric claw-back mechanism for death before and after retirement, any system de facto performs a reverse annuitization. To express it a bit differently, a worker pays for the acquisition of present inheritable wealth (in the present case the PRA balance) with future contingent claims (namely theoretical Social Security benefits). This process raises interesting economic and legal questions. On the economic front, a system allowing for imperfect clawback in case of death before retirement gives individuals yet another tool to shift future resources towards the present in a manner akin to mortgages and home equity loans. From a legal perspective, it is interesting to know whether such borrowing against

\footnotetext{
${ }^{10}$ For a brief discussion on offsetting, see Gustman and Steinmeier (2005).
} 
Social Security is actually coherent with present day limitations on borrowing on future Social Security payments.

\section{Pensions: the Basics}

Fundamentally, old-age pensions can be defined as periodic payments made on retirement or above some specified age. Old-age pension systems may provide insurance against an entire array of risks such as the risks of uncertain length of life and working life, loss of purchasing power and investment risk.

\section{A. Longevity Risk and the Role of Annuities}

Pension plans have the potential to insure people against the double risk of increased life expectancy and uncertain time of death by providing individuals with annuities that pay benefits until the end of a person's life, so called life annuities. ${ }^{11}$ In his seminal paper, Yaari (1965) showed that absent any bequest motive, an individual life-cycle saver would like to fully annuitize his wealth rather than keep it under the form of savings. Annuities allow individuals to focus their financial resources on the states of the world in which they are alive.

The economic rationale behind this observation is rather straightforward. The basic life-cycle model without bequest motives tells us that individuals want to have a continuous real flow of consumption to attain the highest possible utility level, a result known as consumption smoothing. With no life-span and no price uncertainty, the result is pretty easy to attain as individuals simply have to optimally split their lifetime resources among the different consumption periods. When introducing life-span uncertainty, individuals no longer want to hold their lifetime wealth under the form of savings, but rather under the form of annuities, and this from the very beginning of their life. This process is referred to in the literature as continuous annuitization. In the presence of a joy-of-giving bequest motive, Jousten (2001) showed how the intrinsic value of the annuity contract to the individual decreases. The paper showed that it is only for extreme values of the bequest motive that individuals lose their strict preference of annuities over pure savings products in favor of a simple indifference between the two types of products. For other formalizations of the bequest motives similarthough less categorical results — can be derived with some room left for pure savings products. Hence, from a policy point of view, annuities should continue to play a key role in any retirement program. Pure savings products with either lump-sum or phased withdrawal strategies are inadequate tools to ensure coverage against the risk of uncertain death, unless the individuals have other tools at their disposal. One such tool is informal risk sharing along the lines of Kotlikoff and Spivak (1981) who suggested that informal risk pooling within a family can be a viable alternative to formal annuitization.

\footnotetext{
${ }^{11}$ Mackenzie (2005) provides an extensive discussion of the concept of annuities and the different forms they take in the real world.
} 
The logic of annuitization is actually not limited to the post-retirement period. In this sense, the uncertainty on the length of the life would tend to argue in favor of an annuity-based pension system that annuitizes contributions as they appear, instead of accumulating these contributions in a savings vehicle until retirement, and then converting them all at once into an annuity stream. Most public retirement programs belong to the continuous annuitization type, while private pension schemes usually rely on one-off annuitization at retirement or a fixed age. By doing so, private pension plan participants give up a certain degree of protection against longevity risk.

In the same spirit of life-cycle optimization, it should be stressed that the key objectives are expressed in real terms. Indexed annuities best suit this definition, in the sense that they do not only shelter the individual against longevity risk, but also against purchasing power erosion. Nominal annuities are in this sense a strictly dominated product, as they expose the individual to end-of-life loss of purchasing power. Broadly speaking, two indexing strategies are imaginable. The first obeys a pure logic of simple protection against purchasing power loss by means of indexing benefits to the trend of the consumer price index, or some other more targeted price index. The second logic involves indexation to wages. Keeping the starting level of benefits constant, wage indexation implies that beneficiaries of such pensions are granted a share of the gains in productivity realized by the current working generation. Expressed differently, price indexation guarantees some absolute level of consumption that will remain available to retirees, while wage indexation of benefits implies a steady relative position of retirees with respect to the working aged population.

\section{B. The Notion of Actuarial Neutrality}

Besides the risk of longevity, individuals also face uncertainty with respect to the end of their working life. Likely causes are health conditions that either force people to leave the labor market or at the very least make it costly and undesirable to keep on working. Diamond and Mirrlees $(1978,1986)$ study the case of workers forced to retire early due to the unpredictable onset of a disability. In their setting, truly disabled people cannot be separated from those purely claiming to be disabled. They show that the optimal retirement program implies benefits rising with the age at which one starts to draw benefits, but by less than the actuarially neutral adjustment. The intuition for this result is strikingly simple. The desire to ensure a sufficient income level to those who are forced into an early withdrawal from the labor force implies a relatively more favorable treatment of this group with respect to people retiring late. Hence, the slope of benefits as a function of age has to be lower than what it would be if the system were run according to simple accounting principles on an individualized basis. It is worth noticing that the above theoretical finding runs counter to an often proclaimed desirability of an actuarially neutral pension system on the margin of retirement.

As a matter of fact, actuarial characteristics are often mentioned in pension-related discussions. However, there seems to be some confusion on the different terms. Economists and policymakers alike often erroneously use the term actuarial neutrality as a substitute for actuarial fairness. The two terms - both borrowed from the world of the actuarial sciencesare however not the same. The term actuarial neutrality describes situations where a decision is neutral with respect to the actuarial or expected present discounted value of a financial 
flow over time. The question of actuarial neutrality is a multidimensional problem, as it comes up along every single margin of maneuver that an individual faces.

A pension system is, thus, defined as being actuarially neutral at the retirement margin when the net present discounted value of benefits-measured at any given point in time-is unaffected by the decision to retire at age $\mathrm{X}$ rather than at some reference age $\mathrm{Y}$. More precisely, the margin of maneuver is the simultaneous decision to retire from active working life and enter into recipiency of retirement benefits provided by some pension system. The situation of a simultaneous retirement and benefit claiming decision is by far the most commonly observed one in the real world, but it is not the only possible one as the two decisions can easily be separated into a two-step procedure. Coile and others (2002), for example, studied the question of whether there might be an incentive to delay claiming of retirement benefits after the departure out of the labor force. The authors' analysis shows that for some sub-groups of the population, there might be rather powerful financial incentives pushing individuals to optimally divert from this simultaneous retirement and claiming decision. In this spirit, a system is said to be actuarially neutral along the claiming margin when the net present discounted value of benefits conditioning on a constant age of retirement is unchanged when considering different claiming dates. Yet another form of actuarial neutrality of a pension system relates to the margin of additional earnings at any given point in time of one's working life. For this latter margin, the relevant domain is the entire earnings space where workers have a positive elasticity of labor supply.

A system is called actuarially fair, if the expected present discounted value of benefits net of contributions over the entire lifecycle equals zero. Hence, a system-both public and private - can be actuarially neutral along the margins discussed above without being actuarially fair at the same time. Similarly, a system can be actuarially fair at a given age of retirement, without however being actuarially neutral on the margin of retirement.

In the presence of individual heterogeneity along socio-economic and demographic dimensions, it is easy to show that the only way of having both an actuarially neutral and fair stand-alone pension system is to have a system that is perfectly individualized along those individual characteristics. If the system stops short of perfect individualization, some people will necessarily either face distortions along a given margin of maneuver, or be affected by positive or negative net infra-marginal transfers, hence either violating actuarial neutrality or actuarial fairness.

\section{Defined Benefit and Defined Contribution Plans}

The distinction between defined benefit and defined contribution plans touches one of the core ingredients of a pension arrangement. There is however no unique definition of these concepts. In most of the public economics literature the emphasis is put on the extent to which the contribution as opposed to the benefit formula is fixed under the pension arrangement. A pure defined contribution (DC) plan contains no other promise relating to the accumulation phase, nor does it contain any obligation of result at retirement, or later. Pure defined benefit (DB) plans contain benefit promises expressed either in absolute or in relative terms. According to this definition, the identity of the entity granting this guarantee does not matter. 
More recently, the OECD proposed a somewhat more targeted definition. ${ }^{12}$ The motivation for this new definition is based in the special situations that arise in occupational pension plans, particularly in the face of increased accounting requirement on behalf of pension plan sponsors. According to this OECD definition, DC plans correspond to plans where the contribution is the only parameter that is guaranteed by the employer in the case of an occupational plan, or the state in the case of a public plan. DB plans are according to this second definition all plans that are not DC, and hence include some sort of promise in terms of the benefits that are payable in the future. ${ }^{13}$

Disclosure requirements, good practice, and limited risk considerations of DC plans are conceptually similar to those of any kind of investment fund. Strictly informative and nonbinding projections of benefits at retirement are often the only "retirement"-specific note. DB plans are technically more difficult to administer than pure DC plans, both from the point of view of the employer and from that of the fund administrator. DB plans have to keep funding levels and solvency at sufficient levels in order to be able to fulfill the ultimate benefit promise at or after retirement. There is an important role for actuarial calculations and specific investment and liability management to select the types of investment and the maturity of the assets such that they match with the projected pension benefits liabilities.

The distinction between DB and DC plans extends well beyond pure definitional considerations. ${ }^{14}$ They translate into very different benefit structures, with fundamentally different outcomes in terms of risk. Several types of risk are affected. In a pure DC plan, it is the individual or a group of plan participants that ultimately ends up bearing both the risk of longevity and the investment risk prior to and after retirement. In pure DB plans, on the other hand, these two types of risk are generally entirely borne by the employer, the pension fund or the state (as guarantor). ${ }^{15}$ Individuals are, thus, theoretically protected against any kind of fluctuation in terms of the underlying returns earned on the pension asset and the changes in life expectancy. ${ }^{16}$ In between these two extremes, there is an array of different situations, which involve different risk-sharing rules. An example of an impure DB plan would be the case of a pension benefit that corresponds to fixed contributions with a fixed or minimum rate of return on lifetime contributions guaranteed by the plan sponsor. Similarly, such a rate of return guarantee could be used for determining a minimum pension benefit under a

\footnotetext{
${ }^{12}$ When referring to a pension plan, I consider it as a legally binding contract having an explicit retirement objective. For occupational plans, the plan sponsor is often the employer or a group of employers. A pension fund is one possible funding vehicle of a pension plan.

${ }^{13}$ See Yermo (2002).

${ }^{14}$ See Heller (1998) for a discussion of some risk considerations relating to the choice between DC and DB.

${ }^{15}$ Heller (2004) presents an interesting discussion of the risk exposure of governments as a result of explicit and implicit contingent liabilities. One example of the latter derives from the government's likely inability to stay on the sidelines in the face of a major crisis in the (nonguaranteed) private pensions market.

${ }^{16}$ Extreme shocks are however likely to affect individuals even in a pure DB environment as guarantees by the company or the state may become too costly to bear.
} 
conventional DB system. ${ }^{17}$ An impure DC system could, for example, guarantee a fixed or a minimum rate of return. Any such guarantee will ultimately be collectively borne by plan members.

\section{PAYG and the Accounting of Public Pensions}

Independently of the previous categorizations, pension systems can be classified as being either PAYG or fully-funded, depending on the way benefits are funded. In a pure fullyfunded or capitalization system, the contributions of today's working generation are saved and invested to ensure that same generation's retirement needs are met tomorrow. In a capitalization scheme, there is no explicit intergenerational redistribution taking place. The only form in which income is distributed is according to the ownership of factors of production. Hence, the elderly are earning income because they are the owners of the productive assets that the young are working with.

In a pure PAYG system on the other hand, today's contributions are used to pay for today's benefits, hence operating without financial assets and reserves. Most public pension schemes around the world approximate the concept of a PAYG system. As such, these pension schemes do not have any assets to back any future benefit claims based on past and current contributions. PAYG pensions, thus, fundamentally rely on an explicit intergenerational solidarity, as all benefit entitlements are purely implicit.

As a result, it is, thus, not surprising that accounting for the various kinds of pension liabilities is a contentious topic. There is a long running debate on the accounting of pension liabilities incurred by the public sector. Holzmann and others (2004) propose a taxonomy of measures of pension liabilities. Two elements play a key role in understanding the lack of a coherent approach to the question. First, promised future pension payments under a public PAYG pension system do not completely appear in official government statistics (Oksanen 2004, Lequiller 2004). Together with promised health care and long-term care payments, they represent a major component of the concept known as implicit public debt (IPD). ${ }^{18}$ The pension-related IPD is defined as the present value of pension rights accrued up to a given date by workers and pensioners. The reason for this absence of accounting is rather straightforward and basically comes down to the very substance of these future streams: these are promised payments, maybe even called entitlements. But they often stop short of being legally enforceable claim on future resources. Expressed differently, future pension payments are a particular kind of public debt, because they are implicit by nature and they are often easier to renege on. The Italian Dini and Amato reforms that considerably reduced future benefit payout streams are probably the best known examples in terms of the effect on the implicit debt level. ${ }^{19}$

\footnotetext{
${ }^{17}$ In the U.S. context, cash balance plans are an example of impure DB with a fixed rate of return guaranteed by the employer. In Belgium, all DB company pensions have to guarantee a minimum return on the contributions paid.

${ }^{18}$ See Heller (2004).

${ }^{19}$ See most notably Beltrametti (1996).
} 
Absent any such legal differentiation, it can easily be shown that the implicit debt of a PAYG-based social insurance system and explicit public debt are perfectly equivalent from a purely economic point of view, and hence should be treated similarly.

\section{E. Why Public Intervention?}

Public intervention can take a variety of forms, and goes well beyond a purely binary decision between a completely private and a completely public retirement income system. In this respect, it is helpful to slice down the retirement scheme into the different functions that it fulfills, and consider whether public intervention is useful at any of the stages considered. To start off with, there is the question of membership in the program, which can be completely left to private decisionmakers or put under public scrutiny. Second, there is the question of whether the financial inflows into, and outflows out of the system are fully under private control, or whether some public institution or administration should be put in charge of either one of those. Third, there is the question of knowing which role should be reserved to the public and the private sectors in the management of the collected resources, as well as in what type of assets these resources would be invested. In this context, it is perfectly imaginable to have a private fund management of an otherwise public pension scheme. Fourth, there is the question of what role the government should play in terms of regulating the behavior of private actors, as well as what kind of reinsurance protection or other guarantees the public sector might be able to provide for an otherwise private system.

At this stage, it should already be stressed that any of the below reasons for private market failure have to be seen as necessary conditions for public intervention, but by no means as sufficient conditions. There is fundamentally no reason why a government would necessarily be better equipped to deal with any of the below limitations, and thus it is only to the degree that the public authorities have better tools at hand that there might be a role for public intervention.

Redistribution. All aspects discussed so far do not involve a stringent role for the government or the public sector more generally. However, when looking at the real world, public intervention abounds. An obvious first motivation for such intervention might be a desire to redistribute income. Whereas any insurance scheme necessarily involves some ex post redistribution between individuals, there might be a desire to go one step further and also redistribute resources between different individuals on an ex ante basis.

Adverse selection. Adverse selection arises when heterogeneous individuals have a possibility to hide their true characteristics and take strategic actions. Adverse selection is a classical problem of asymmetric information and examples of adverse selection abound all across the insurance industry. As such, the fundamental problem that pension plans face and those of any other kind of insurance contract are no different.

Adverse selection generally leads to an economic outcome that has to be qualified as suboptimal, either because markets fail to exist or because they operate with incomplete coverage for some risk groups. The reason is simple. Individuals will be able to exploit their informational advantage when confronted with any pricing strategy. Using British data, 
Cocco and Lopes (2004) present empirical evidence that individual characteristics play a key role in the choices made among different public and private retirement plans and thus illustrate the relevance of such considerations for pension systems.

Remedies for adverse selection are well-known. On the one hand, there are remedies that attack the roots of the problem by attempting to improve the information available to the insurer. The most common example is the medical checkup that life insurers often require prior to signing a new contract. On the other hand, there are policies that restrict individuals' abilities to adversely select into a different risk group. In this line of thought, compulsory coverage under a group pension scheme for all workers of a given company, or for all citizens of a country may play this role. Such compulsory membership usually comes at a cost, as people are forced to participate at average annuity rates rather than risk-group specific rates. It is thus ultimately a question of evaluating the costs versus the benefits of such a policy. Eckstein and others (1985) showed that there is a clear welfare improving potential for a compulsory pension scheme. Their result does not, however, imply that a public retirement system replaces or eliminates the role of markets as they show that there is substantial room for private complementary or supplementary schemes next to the basic public scheme.

Moral hazard. Moral hazard is the second type of asymmetric information that is often advanced as a reason for public intervention. In the insurance industry, moral hazard arises because individuals are able to take hidden actions that have a potential impact on the outcome of the insurance problem.

In pensions, one of the most frequently encountered moral hazard problems relates to early retirement and has to be seen as a rather striking example of the fact that public intervention does not necessarily help. Public insurance systems generally allow for earlier withdrawal from the labor force when a person meets some more or less stringent disability criteria. Similarly, many European social insurance schemes allow for early withdrawal from the labor force when the person works in a company or an industry that undergoes more or less severe restructuring. In this situation, there is a substantial risk that workers and their employers might find it optimal to reduce the labor supply and demand for older workers in order to benefit from these otherwise inaccessible early retirement options.

Myopia and paternalism. Absent any public intervention, some people will simply save insufficient amounts. The reasons for this may be multiple, but can summarized as resulting for strong preferences for the present. The classical example is clearly myopia that makes people over-consume in the short run because they do not attach a (sufficient) value to future consumption.

Myopia may clearly be a cause for public intervention when the government takes a paternalistic approach and intervenes ex ante to assure that people save sufficiently. Most compulsory and structured public retirement income systems would satisfy such a criterion. The compulsory membership reduces adverse selection potential but also makes sure everybody contributes. The structured benefit claiming and contribution rules ensure a 
dampening of moral hazard and myopia that would otherwise lead towards under-saving for the old age and excessive early retirement behavior.

However, myopia might also justify a different kind of public intervention, namely one that works ex post by providing a basic minimum pension benefit, that can either take the form of a demogrant for people above a certain age or the form of a means-tested minimum benefit. In a recent World Bank publication, Holzmann and Hinz (2005) revise the by now standard three-pillared pension structure to integrate a pillar zero. The authors recognize the role of such a pillar zero particularly in the developing world, notably because of insufficient coverage of segments of the population under any of the other pillars.

But beyond developing countries, the role of a minimum benefit is of an increasing importance even in developed countries. In this context, it suffices to refer to the diminished role of the universal public pension pillar (pillar 1) in favor of compulsory (pillar 2) or voluntary (pillar 3) pensions. Any such shift will no doubt increase the political role of a pillar zero, if only because the group of people participating in pillars 2 and 3 is generally strictly smaller than the one participating in public sector pillars.

Administrative and decisionmaking costs. Administrative and management costs are an important factor influencing the net return that people can earn on their pension assets. Similarly, decisionmaking by individuals is a costly process, both because of the explicit and implicit charges that individuals have to face when acquiring the necessary information and because of the expenses that pension providers incur to influence this decision.

Public intervention in this area usually takes two forms. The government can require group purchases or organize a universal public pension system reducing the cost per contributor quite considerably. The underlying logic is one of economies of scale. The second form of intervention is regulation of the industry. This may be done by requiring minimum information to be revealed to the plan participants or by enforcing caps on the financial charges that providers are allowed to charge. Another way of reducing the decisionmaking costs has been discussed by Sheshinski (2003). The author concludes that in the presence of bounded rationality restrictions on the set of alternatives may produce socially preferable outcomes. Along the same lines of bounded rationality, the setting of default options for asset allocation in defined contribution plans has been heavily researched topic. (See for example Laibson and others, 2003.)

Incomplete financial markets. Under an assumption of perfect capital and financial markets, individuals would find optimal tools for protecting themselves against all kinds of possible risk. The reality looks somewhat different in the sense that private markets still do not provide a full set of products permitting an adequate coverage against a series of risks. The most obvious ones are inflation, longevity, and aggregate investment risk against which private markets can only offer extremely limited protection. Often, private pension arrangements only provide for nominal annuities, hence fully exposing the individual to inflation risk. Hence, a role for the public sector might be to explicitly provide such 
insurance, either by setting up an inflation-proof public pension system or by providing private insurers with products to adequately shelter against inflation risk. ${ }^{20}$

The public sector intervention can also be more subtle. The previously cited Coile and others (2002) illustrates such an example, where within the U.S. Social Security scheme a marginal annuity market de facto exists because of the possibility to decouple the date of retirement and the date of claiming.

\section{PENSION REForm AND PRA}

Justifications for pension reform proposals abound. The most frequently advanced one refers to the profound demographic change that most developed countries are currently going through, but clearly limiting the call for reform to this argument would be leaving out some other key developments. The present section focuses on three fundamental motivations for reform, while the next section addresses some specific design issues that might plead in favor or against reform of the current system.

\section{A. Demographics and PAYG}

When considering the PRA reform proposal from this PAYG point of view, it has to be stressed that none of the key aspects of the proposal seems to have a beneficial impact on the financial sustainability of the Social Security system as such, since it does not directly affect any of the parameters mentioned above. This view is likely to be incomplete. First, there is the potential for a direct effect on public finances defined more broadly, as a consequence of the difference between the interest rate at which the government borrows money on the markets, and the effective interest rate it charges under the claw-back provision to individuals that opt for the PRA system. Indirect effects on Social Security are obviously also imaginable. One such indirect mechanism could work through the savings channel. If aggregate savings actually go up and as a result of this increase in aggregate savings aggregate investment in the U.S. economy also goes up, then there is a potential for higher wages, which could ceterus paribus lead to higher revenue from contributions. Another indirect mechanism could be an increase in the average retirement age, which has beneficial implications for the Social Security system given its lack of actuarial neutrality on the margin (Gruber and Wise, 1999, 2004, and 2005). Such an increase in the average retirement age could result as a direct consequence of the desire of people to continue to contribute to the system with its low administrative charges and well-regulated products, hence making them retire later. Similarly, it might happen that individuals will want to work longer to make up for a possible bad draw in terms of the performance of their PRA in earlier working life.

\footnotetext{
${ }^{20}$ The optimal allocation of longevity risk is also limited by market incompleteness. Visco (2006) discusses some recent developments on the market for longevity-based financial instruments and reports the introduction of the first mortality-related bonds.
} 
It should be pointed out that a demographic aging process does not per se mean that a crisis or a reform of a pension system are inevitable. The differentiation between the terms crisis and reform is made on purpose. Demographic change is not inevitably going to result in a crisis of any kind of pension system. Theoretically, at the very least, it is imaginable to have a pension system that is built on structures that are capable of coping with the demographic challenges from within, simply by obeying a set of rules that are not exposed to the abovementioned risks. This could notably be the case in a system where the monthly benefits paid out to retirees decrease automatically as life expectancy increases. A prime example is the Swedish Notional Defined Contribution (NDC) social insurance scheme, where benefits are life-expectancy-linked and, thus, the system is sheltered against increases in longevity. But even under such a crisis-proof system, the country might face pressure towards reform as a result of demographic aging. Expressed differently, though fiscal soundness may insure the survival of the pension system itself, it may equally give rise to calls for reform if it involves socially unacceptable outcomes in terms of old-age income and consumption levels and distribution.

Equally, it should be noted that the above demographic challenges are by no means limited to the domain of PAYG systems and extend to both DB and DC plans. The problems of some U.S. DB plans can serve as an example. Some companies have to make up for their pension funds funding shortages at times where their ratio of workers to pensioners has dropped to levels well below 1 , hence threatening both the existence of the company and the financial situation of the pension fund.

But even DC plans are fundamentally exposed to demographic risk as the returns on the assets of the system are influenced by the shape of the labor force. To see the relevance of this point, it is easiest to first focus on a closed economy setting. As the demographic transition occurs, there will be a period characterized by a relative abundance of capital with respect to labor, and hence relatively low returns on the capital. Börsch-Supan and others (2002) show that such an effect can be absorbed with capital exports to foreign countries facing a different timing of their demographic transition. Jousten and Legros (2005) illustrate that a demographic shock affecting two countries that differ in the way their pension systems are financed will cause the country with the capitalization system to bear some of the transition burden of the PAYG country through international capital flows. IMF (2004) concludes that the existing empirical and theoretical literature suggest that baby boomers' retirement behavior may well cause stock prices to be adversely affected, with the obvious consequences in terms of the retirement wealth individuals would dispose of. Similarly, the equity premium, i.e., the excess risk-adjusted return of stocks over bonds, may equally be affected.

\section{B. Individual Savings and Returns}

Faced with the risk of lower benefits from the PAYG system, an often recommended strategy is to make sure that individuals put more resources aside for their retirement. Such a strategy can be attained either by encouraging people to save more, or to purchase more annuity products. Both strategies involve shifting net resources in present discounted value terms towards the future and are based on the idea that rates of return on such products would be higher than those in a PAYG system. Geanakoplos and others (1998) analyzed the question 
and found evidence that such a situation cannot be taken for granted in reality. Hence, one way of approaching the PRA proposal is to analyze whether it actually generates a clear-cut incentive for such a resource shift to the future.

During the accumulation phase for retirement pensions, defined contribution assets accumulate in the worker's PRA just like any regular savings product. At first sight, the major differences with respect to more traditional savings and retirement products are limited to the planned complete denial of access to the accumulated resources prior to retirement as well as the limitations on withdrawals of the accumulated funds once retired. ${ }^{21}$ Hence, at first sight, the key decision variable in every individual's financial investment strategy might seem to be a comparison between the expected returns earned on other investment products, and the return earned on the PRA.

However, when inspecting the product somewhat closer, it becomes clear that this is actually the wrong approach to the question, as both products are not really comparable. The most striking reason for this is the offsetting rule that leads to a reduction of Social Security benefits once the worker retires as a function of the contributions diverted away from Social Security. Expressed differently, individuals do not only choose between a PRA and another investment vehicle, but rather also simultaneously between two different scenarios in terms of Social Security benefits. The benefit offset transforms the PRA into something that resembles a fixed-interest loan that the worker takes out to invest in the financial markets and that has to be reimbursed later on in life. To be a bit more precise, the worker obtains a loan of an amount equal to the diverted contributions from the Social Security Administration. The interest rate on the loan corresponds to the interest rate which the administration uses in its actuarial calculations at age 65, thus, in the above-mentioned example close to 3 percent. ${ }^{22}$ According to the administration's reform proposal, this loan is repayable after retirement through monthly repayments under the form of foregone Social Security benefits.

The key problem that the contributing PRA investor faces can be rephrased as a risk-return tradeoff. Risk-averse fully rational PRA investors will only be willing to participate in this loan-investment alternative if the expected average return is sufficiently strong to compensate for the extra risk that the person takes with respect to the alternative which is an absence of participation in the scheme. Shiller (2005) addresses this question for various asset portfolios. Using a simulation approach, he shows that there is a substantial risk of obtaining a lower return in the PRA than the interest rate that is used in the offset calculation. Further, he finds that under conservative assumptions on the returns in line with historical international returns, the median rate of return would actually be lower than the rate used for

\footnotetext{
${ }^{21}$ As the share of retirement income out of investment-based individual accounts increases—such as under the PRA proposal - the denial of access and the protection of the accumulated funds becomes an ever more important question.

${ }^{22}$ The relevant interest rate in the decision problem above depends both on the announced rate, as well as on the question of whether diverted contributions have to be paid out of PRA accounts of people that die before retirement.
} 
computing the offset. The latter finding would, thus, involve risk-taking while at the same time giving up average returns, a clearly suboptimal strategy.

The proposed option of a government bond fund with a guaranteed rate of return above inflation would seem to be an exception to this rule of risk-return tradeoff. All other things equal, individuals would mechanically prefer to invest a maximum in this asset for a rate of return that is higher than the one used in the offset calculation. The opposite would be true if the return is smaller. This type of corner solution actually points to an interesting problem. If, on the one hand, the rate that is used in the offset calculation is set once and for all in advance, while the rate of return on these inflation protected bonds likely continues to fluctuates with the market, we should observe a large degree of instability in the incentive to participate in the PRA. Expressed differently, when market long-term interest rates change, so do the incentives to take the once-and-for-all decision to participate in the program. If, on the other hand, the rate used for the offset calculation actually varies with the market rate it raises an interesting question for both risk-free and risk-taking investment strategies. Effectively, the PRA investors would not only possibly face risk on the return side of their investment, but also interest rate risk on the loan side of the problem. For the special case of co-movement of the interest on indexed bonds and the interest used for the offset calculation, this point actually leads to a fundamental question, namely why these two rates would be different. Indeed, any difference will lead to mechanical behavior involving either a mechanical subsidy of the government to the individual (when the rate on bonds is higher), a mechanical refusal of the individual to participate (when it is smaller), or a complete indifference on the pure basis of rates of return. ${ }^{23}$

Hence, to sum up, the choice of participation in the PRA program essentially reduces to a bet on future returns on the financial markets. The ensuing effect in terms of additional resources does not, thus, necessarily lead to a net shift of resources towards the future due to the suggested offsetting rule after retirement.

Quite to the contrary, the literature on IRA and 401(k) retirement savings indicates that such a policy might end up decreasing the resources allocated to the future. The logic is simple: faced with a higher nominal PRA account balance, individuals might be tempted to (completely) undo the effect of increased PRA savings by reducing their alternative savings efforts as they may see PRA assets as substitutes for other retirement assets. ${ }^{24}$ Even though such a strategy may be completely misguided from a purely financial point of view, the risk is nonetheless very real as people might underestimate the liability of reduced future Social Security benefits they incur when entering the PRA system.

\footnotetext{
${ }^{23}$ However, even when rates of return are equal, this does not mean that people do not have strong preferences for either one alternative, purely based on the very different rules with respect to annuitization, spousal, and survivor benefits, just to cite a few examples.

24 The classical references are Gale and Scholz (1994) and Poterba and others (1996). Using the same data, the former found no net effect of IRA tax incentives on savings whereas the latter found a positive effect.
} 


\section{Increased Aggregate Savings}

Faced with the demographic challenge to the PAYG-financed Social Security program, the ensuing observation of need for action should not, thus, be seen as a surprise. The same probably also holds true for the tendency to move towards a capitalized system given the nowadays generally higher returns on capitalization systems as compared to PAYG systems. At the aggregate level, the tendency to shift towards a savings-based system is a somewhat less obvious case to make.

Neoclassical growth theory relies heavily on the link between savings, investment, and the growth of the economy. In a closed economy setting, it can be shown that an economy that increases its savings rate will in the long-run access to a higher level of output per worker while having an unchanged long-term growth rate. The result implies that any positive growth effects of additional savings are only observable during a transition period and perpetuate themselves in a level effect but not a rate of growth effect.

The situation is slightly different in an open economy setting, such as the one of the United States, where any insufficiency of national savings can be compensated by imported savings from abroad. Within the context of the proposed U.S. reform, it is worth noting that a stimulation of aggregate savings does not necessarily imply higher Gross Domestic Product (GDP) growth, but clearly implies a somewhat less marked reliance on capital imports from abroad. Whereas this might be a worthy aim in itself, it has to be dissociated from any pure growth considerations. But in spite of these unambiguous results in terms of output, excessive savings may actually reduce the long run steady state consumption levels of individuals.

Beyond these long run considerations, it is important to emphasize that any increase in aggregate savings will, in the immediate term, lead to lowered private and/or public consumption (see Burtless, 2001). The rationale behind this logic is simple. For a given GDP level at the point of departure, it is only possible to increase savings if somebody's consumption decreases. A first example would be to cut retirement benefits to those currently on Social Security while at the same time keeping the Social Security contribution rate unchanged. Such a strategy would improve the public sector's balance sheet and lead to higher public sector savings, and thus higher national savings. A similar effect could be attained if the PRA were conceived as a complement to current Social Security contributions rather than the proposed substitution.

Two other mechanisms may also influence the level of aggregate savings. First, making implicit government debt explicit could affect the spending and savings behavior of the public sector if only by making the intertemporal budget constraint more explicit and transparent. Second, the introduction of a PRA or any other form of retirement savings device could generate fresh additional net savings at the individual level, which would increase private savings. Engen and Gale (1997) find that though increased prefunding of (public) pension liabilities is a necessary condition for increased national savings, it is by no means a sufficient condition as private savings does not necessarily increase in line with increased public dissaving. As discussed before, the PRA proposal is unlikely to deliver on these margins, as the increase in private savings under the form of PRA is mechanically 
undone by a decrease in public sector savings due to the need for issuing bonds to finance the transition. While the precise net savings effect of the PRA are hard to predict, it is likely that they are going to be small in absolute value.

\section{Accounting for Private Sector Pensions}

In the private sector, accounting rules for pensions have recently undergone some significant changes. The most prominent change is no doubt the progressive introduction of the International Financial Reporting Standards (IFRS) for listed companies in a long series of countries, and more particularly the accounting standard known as IAS 19 that deals with pension liabilities of companies. ${ }^{25}$ In the United States the existing accounting standards (FASB 87) are largely consistent with the current version of IAS 19. Whereas previously national governments applied very different rules to their companies, IAS 19 represents a first attempt towards a common way of treating pension liabilities. Key to IAS 19 is the concept of "constructive obligation.” This term is meant to precisely go beyond the purely legal aspects of enforceability of claim and considers that companies have to account for claims that represent "an obligation that derives from an enterprise action where: (a) by an established pattern of past practices, published policies, or a sufficiently specific current statement, the enterprise has indicated to other parties that it will accept certain responsibilities; and, (b), as a result, the enterprise has created a valid expectation on the part of other parties that it will discharge these responsibilities."26

In this sense, IAS 19 positions itself somewhere in between the notion of a pure promise without any backing and a legally recognized future claim. Yermo (2003) discusses some of the practical difficulties that arise when classifying pension plans in various countries. By their very nature, pure defined contribution plans, where the employer's role is strictly limited to the original contribution without any obligation for result, do not have to be accounted for in corporate accounts, as they do not comprise an obligation on behalf of the company. As soon as there is deviation from a pure defined contribution plan, the pension plan theoretically becomes IAS 19 relevant. Under IAS 19, companies are required to provision for future benefit liabilities. If the plan is based on final salaries, companies have to project the liabilities on the basis of projected wages instead of current wages. Further, assets valuation has to be based on market values and benefit obligations have to be discounted using current market rates for a similar duration as the pension promises, hence implying volatility in balance sheet liabilities. ${ }^{27}$

\footnotetext{
${ }^{25}$ For European Union countries, the so-called IAS Regulation (EC)1606/2002 concerning the application of international accounting standards was adopted on July 19, 2002 by the European Parliament and the Council.

${ }^{26}$ See Lequillier (2004).

${ }^{27}$ One "insurance" strategy to escape the volatility would, thus, be to invest in long-term bonds such as to have assets and liabilities move in parallel.
} 


\section{E. Accounting for Public Sector Pensions}

The contrast between the way pension liabilities in private and public pension schemes are accounted for is at the center of some recent research, but also of some recent political decisionmaking. Pitzer (2002) and Oksanen (2004) address the question of a more comprehensive accounting for pension liabilities. Apart from a general aim of setting the public and private sectors on equal footing, an important practical reason also exists: pension liabilities are sometimes shifted from a corporation to the government against a compensatory payment, often a lump-sum. By doing so, companies are able to offload their pension liabilities and risks to a government entity. Such a transaction clearly satisfies all characteristics of a purchase of an insurance contract, as it means offloading risk against payment of a "premium." On the government side, demand for such transaction simply stems from the fact that they can usually book the lump-sum as current income in the yearly budget, while at the same time not having to recognize the implicit pension liability anywhere.

The pending introduction of IAS 19 has clearly played the role of a catalyst in this domain. The most recent example is no doubt the harmonization and the transfer of the banking sector's pension plans in Greece just prior to the introduction of IFRS in Greece at the end of June. As a result of the reform, a government entity has taken over formal pension obligations eliminating the otherwise inevitable requirement to include these pension liabilities on the balance sheet. Other examples of such "pension deals" abound, such as the sale by the Belgian telecoms group Belgacom of its statutory employees' first pillar pension plan to the Belgian state in late 2003 against a cash payment of EUR 5 billion as a compensation for pension liabilities resulting from past earnings. This sale can be seen as an important step on the way to the IPO of Belgacom stock on the Euronext stock exchange in early 2004.

Two interesting parallels come to mind when thinking about the PRA proposal. First, the offloading of pension liabilities onto a government entity has an impact on the implicit and the explicit debt levels that the public sector faces. While the choice of the these "pension deals" of European governments are largely motivated by an objective of reduction of current explicit debt levels (for example to satisfy the Maastricht debt criteria), the logic of the PRA proposal seems just to be the opposite, namely making implicit debt explicit. In line with the previous discussion, this shift of emphasis from one type of debt to the other should clearly be expected to have implications for future policy choices. These effects can be expected to go well beyond the already discussed savings effects as implicit debt seems to be much easier to adjust and renege than explicit one. Expressed differently, keeping pension promises implicit rather than making them explicit and legally enforceable appears like an important economic policy tool in its own right.

The second parallel relates to the fact that in neither case is there a fundamental change in the net pension liabilities of the economy as a whole, neither at present, nor in the future. The key change that is taking place is purely a change in the allocation of risk among the different actors in the economy. A common feature of the two types of reforms is that both PRA and "pension deals" shift risk away from the corporate sector. The receiving entity is however different under the two alternatives. "Pension deals" shift the pension risk from some specific 
companies or sectors to the public sector. PRAs shift risk away from the employers and the public sector to individuals as PRA are pure DC vehicles, as opposed to the fundamentally DB based structure of Social Security. Under the rules of Social Security, future contribution hikes cannot be ruled out on an a priori basis. The shift to PRA would make such hikes less likely as the share of contributions going towards the accounts would largely not benefit from outcome guarantees. PRAs thus de facto shift risk to individuals, most notably longevity and investment risk.

\section{FURTHER DESIGN ISSUES}

Beyond these often discussed motivations for reform, pension reform usually has implications on a series of other factors, which are often left out of the public debate. The discussion below focuses on a few considerations relying both on international experience and on the lessons from the private pensions sector. The motivation for this emphasis on particular design issues basically boils down to a profound belief that these issues are of such a scope that they can fundamentally alter the judgment on the desirability of the current system and of proposed reforms thereto.

\section{A. The Problem of Early Retirement}

At a time when demographic factors are threatening the PAYG financed public pension systems, many countries are exposed to a second and this time purely behavioral trend that reinforces the above-mentioned pressures. The most immediate indicators of increased early retirement behavior are no doubt the substantial fall in average retirement ages around the developed world, sometimes reaching levels as low as 58 years in some European countries. Falling participation rates reveal yet another view of the same problem. ${ }^{28}$

At the root of this trend towards earlier retirement lie strong incentives that both the workers and the employers often face to leave the labor force early. These incentives were first documented in an internationally harmonized form by the different contributors to the Gruber and Wise (1999) volume. In the U.S. context, Gruber and Wise (1999) document a rather striking finding of actuarial neutrality of the Social Security system for average- or mediancareer paths. As such, this result would imply the absence of incentives for early retirement stemming from the side of the public retirement system. However, even in the U.S. context there is some level of early exit from the labor force as Herbertsson and Orszag (2001) show. One of the factors that help square these two observations is the heterogeneity in the population leading towards stronger incentives for early exit for some, while leading to strong incentives to stay on for others. Another factor is no doubt the presence of sometimes heavy incentives towards early retirement under some private pension arrangements. ${ }^{29}$

\footnotetext{
${ }^{28}$ See Blöndal and Scarpetta (1998).

${ }^{29}$ The most obvious case is the one where the private scheme compensates the worker for any actuarial reduction factor the individual might be exposed to when retiring early under the provisions of the public scheme.
} 
The strong incentives towards early retirement usually go well beyond the pure limits of retirement income systems, be they public or private. Often, other programs covering secondary risks such as sickness, disability, and unemployment play a major role in the incentives people face. First of all, access to these systems may not necessarily be closely monitored at all times, possibly leading to higher take-up, and ultimately earlier withdrawal from the labor force. The Belgian unemployment insurance and the Dutch disability insurance are no doubt the classical examples of programs, which have been partly diverted from their original objectives to serve as early retirement pathways by providing financial resources to early retirees not yet eligible for regular retirement benefits. A second and linked effect of these systems is that individuals who experience spells on these replacement income systems are often sheltered from a negative impact on their regular pension by a total waiver on contributions during these spells while continuing to enjoy full benefit accrual as if they had worked. Last but not least, such secondary-risk programs also often allow individuals to escape the effect of early retirement penalties that would be applicable under the regular pension scheme.

While the financial implications of the purely demographic challenges are rather well understood, the same clearly does not hold true for the overall costs of the early retirement programs. The explicit and implicit costs of early retirement programs are often hard to evaluate as they are willingly or unwillingly split among a series of different actors and budgets. In an interesting study, Herbertsson and Orszag (2001) computed the cost of the use of early retirement provisions as a fraction of potential GDP that the country could attain with full use of their productive capacities, hence also the older workers. They document that the implicit cost of early retirement behavior amounts to a stunning 15 percent of potential GDP in the case of Hungary and Belgium, whereas it is closer to 5 percent for the United States, Sweden, and New Zealand.

A move towards PRA's will likely have consequences in terms of the skewed incentives individuals face towards earlier retirement under the current Social Security and other private pension rules. First, given that PRA are purely optional, the risk-pool of people selecting to participate in PRA will likely not correspond to the risk pool of people in the population at large. This selection will undoubtedly lead to different pricing patterns than those implicitly applicable within the scope of Social Security. Second, given that everybody does not have to annuitize, this selection will only be reinforced. By allowing this double selection into annuities, the proposal sacrifices the key advantage of mandatory annuitization. It gives every individual the option of converting to an (imperfect) annuity, thus, in some sense, fully subjecting the market to adverse selection through strategic annuitization. All else equal, people with a higher life expectancy have a bigger incentive to convert their lump-sum asset holdings into annuity payout streams than people in a worse physical condition.

The option not to annuitize may actually lead to an even more striking outcome. Theoretically, it is very plausible to argue that the introduction of PRA may cause some individuals with a strong preference for the present (myopia,...) to opt for the PRA, even in the presence of a weaker rate of return profile. Though this might arguably be considered a purely individual financial decision, it remains a rather odd side-effect within a retirement savings proposal. 
But even from a more macroeconomic point of view such a shift towards PRA and the ensuing individual reoptimization will no doubt have substantial effects, as it reforms the pension landscape by leaving the insurance programs for some other secondary risks unchanged. One such link is illustrated by Diamond and Sheshinski (1995) who show the close interaction between Social Security's old-age and disability insurance programs. The paper shows that changes in the level and the award frequency of disability benefits have a strong effect on early retirement behavior under the old-age insurance program.

\section{B. Economics of Guarantees}

Pensions are often associated with the need for some form of protection mechanism in order to make sure that the benefits satisfy at least some minimum criteria. Such protection mechanisms can be organized within a given pension income system but obviously also outside of the strict limits of such a system. For example, most developed countries have some sort of dedicated public old-age income support system set up to cater the needs of elderly people not benefiting from sufficient other income source.

The issue of guarantees arises equally in the context of public and private programs and in DB and DC systems. The guarantee is usually rather explicit in a pure DB plan. But even many other types of plans contain some guarantees. While many possible forms exist, they can be classified into two broad categories: minimum benefits and rate of return guarantees.

Minimum benefit guarantees essentially boil down to the very basic idea of a social safety net. Applied to the field of private pensions, it corresponds to a tool ensuring that people do not find themselves with insufficient resources in retirement, independently of their investment strategies. This type of guarantee is frequently used in countries that rely predominantly on investment-based systems, like for example Chile. Countries with a substantial public system usually do not have major minimum benefit guarantees applicable to private pensions, simply because the public first pillar systems in some sense play that role.

Minimum rate of return guarantees on the other hand are designed to shield people more generally against investment risk independently of their position in the income or wealth distribution. These guarantees can be applied either on a purely annual basis, or alternatively at the final term of the product.

When confronted with a final term guarantee, the guarantee only plays either at retirement, death or exit from the pension plan and thus exposes the individual account holder to different risks. First, it makes it very hard for the individual worker to follow the evolution of his pension wealth. Expressed differently, if the returns are bigger than the guaranteed rate in one year, this does not mean that the affiliate will automatically benefit from this excess return as the excess could as well help to make up for the insufficient return of another past or future year.

Second, the legally mandated guarantee mechanism does not assure the pensioner that he will actually benefit from the announced rate of return until retirement, as such mechanisms 
generally allow for a revision of the guaranteed rate when market conditions change substantially. ${ }^{30}$ The guarantee may thus suffer form the absence of formal and enforceable commitment to make it credible as it is subject to change in the future political process. Such a guarantee thus represents from the very outset an inherent implicit financial risk for the individual affiliate as the true economic value of the guarantee is uncertain until the guarantee comes to play at exit, retirement, or death.

Guarantees suffer from severe moral hazard problems, as people might be induced to excessive risk-taking by the pure presence of these insurance mechanisms. The risk-taking might even be reinforced by the presence of some other social programs. For example, it is not uncommon to find more generous health-related benefits for the elderly linked to income testing in retirement, as for example happens under the U.S. Medicaid program. Any such link obviously reinforces the moral hazard involved. Different alternatives are imaginable to contain the moral hazard in the area of private pension savings, such as simply restricting peoples' investment choices to a limited set of pre-selected portfolios. Another way of coping with the moral hazard problems is to completely sever the link between the insured amount and the actual investment behavior of the person. This latter policy would imply basing the insurance coverage not on observed risk, but rather on the performance of a hypothetical portfolio that has a moderate risk. By doing so, people continue to benefit from insurance against general market reversals, whereas at the same time fully assuming the economic and financial consequences of individual deviations from such a "conservative” portfolio.

Both guarantee mechanisms also clearly come at an economic cost to the affiliate or the taxpayer, as there is no such thing as a free lunch. Expressed differently, if the guarantee actually represents a real protection for the individual, then it has to be that it is somehow implicitly or explicitly priced. Explicit pricing would occur if the individual or the pension organization would buy coverage against downward risk from an insurer or under the form of an option contract on the financial markets. Implicit pricing occurs when no such purchase takes place and the coverage is simply reflected in the return structure that the individual faces on his pension assets, or in a higher tax burden elsewhere to finance an independent social safety net. Lachance and Mitchell (2003) use an option valuation technique to infer the cost of an explicit guarantee provided by a pension fund itself and show that the costs are very substantial when portfolios are heavily invested in stocks rather than bonds. Their intuition is simple: stocks have a higher volatility and, thus, a higher chance of activating the guarantee than bonds. A corollary of the result is that increasing the share of bonds reduces the cost of the guarantee. In terms of the pension policy of a plan sponsor offering such a guarantee, the findings of Lachance and Mitchell (2003) imply that they might have an incentive to opt for more conservative fund strategies and more insurance to diminish the likelihood of having to top fund assets in the future, thus significantly reducing the range of assets returns potentially accessible to the individual pensioners.

\footnotetext{
${ }^{30}$ See for example the Belgian law on complementary pension that allows for a revision of the future guaranteed rate of return.
} 
The proposed PRA would not provide any explicit guarantee. Hence, individuals are fully exposed to investment risk, as their benefits will be reduced according to a formula where effectively observed returns do not matter. While the offsetting with a fixed interest rate clearly eliminates all potential for moral hazard, it also eliminates any kind of insurance mechanism against bad investment draws on the side of the individual.

\section{Who Guarantees Private Sector Pensions?}

Three broad categories of entities can issue guarantees: the employer in the case of a workplace-related pension, the pension fund and the public sector. As discussed below, the distinction between these three is crucial as they imply very different outcomes both in terms of the value of the guarantee and the way it affects the different entities concerned.

When the guarantee only plays at exit, retirement, or death, such as with minimum benefit guarantees or term rate of return guarantees, any possible shortage of funds only becomes apparent at these key stages. This can be problematic. Consider the case of a guarantee issued by the employer. If the issuer of the guarantee is still around at that time, this gap-funding policy might lead that company towards having to fund gaps of old workers rather than spending the money on its current workforce. Expressed differently, there is an intergenerational redistributional effect, as the gap between younger workers' productivity and their net wages will have to increase to face the higher financing costs of the retired workers' pension obligations, independently of whether these young workers belong to the same pension regime or not. Similar intergenerational redistribution arises when the issuer of the guarantee is the pension fund rather than the employer, with this time redistribution occurring from young plan affiliates towards retirees.

But the issuer of the guarantee might equally no longer be around or not have the necessary financial clout to face the burden at the time the gap has to be bridged. This means that the guarantee could ultimately either be completely worthless or ultimately be borne by some public entity that is playing the role of guarantor of last resort. Real-world examples of the latter system abound, as governments usually try to increase the confidence in the system by complementing privately issued guarantees by a backup provision by a public or quasi-public authority, either financed through some insurance premium levied on the covered amounts or out of general government revenue. The rationale for such an institution is most easily understood when thinking about aggregate risks that private insurance companies cannot adequately shelter their customers against.

In the United States, the Pension Benefit Guarantee Corporation (PBGC) plays this role of public stabilizer for most defined benefit and cash-balance plans. ${ }^{31}$ The PBGC was created by the Employee Retirement Income Security Act of 1974. The aim was to encourage growth of

\footnotetext{
${ }^{31}$ American defined contribution plans are not covered by this insurance given that investment risk is entirely borne by the plan participants, in line with the definition of such plans by the OECD. Some European countries divert from these pure principles by imposing minimum rate of return guarantees on products that are also broadly classified as defined contribution plans.
} 
defined benefit pension plans, to provide timely and uninterrupted payment of pension benefits and to keep pension insurance premiums at a minimum. The entity is financed by means of compulsory contributions of all plans eligible for coverage under the PBGC terms. ${ }^{32}$ The PBGC arguably leads to moral hazard in the retirement income market in line with experience from deposit insurance schemes applicable to bank savings accounts. It can easily lead to excessive risk-taking and too frequent reliance on the guarantee. Expressed differently, the PBGC may eliminate the negative consequences of default risk for current and future pensioners by generating systematic risk-overexposure of pension funds and hence creating a new kind of aggregate risk.

The recent past can serve as an illustration of this principle. After a series of corporate failures and restructurings, the PBGC's net position has been seriously challenged as it has to assume the financial responsibility for pension fund shortages. PBGC (2005) documents that over the last 4 years, the net balance sheet (assets minus liabilities) of the PBGC has worsened dramatically to an approximate negative value of US\$24 billion in 2004, with the numbers having taken yet another hit in 2005 with the takeover of the under-funded pension plan of United Airlines. In the face of this risk of an outright financial failure of the PBGC, various proposals to revamp the system have been advanced, aiming at a lower risk exposure of the entity that many companies have simply used as a cheap way to get rid of underfunded pension schemes. The 2006 Pension Protection Act tries to address some of these concerns by reducing incentives to under-fund defined benefit pension plans and increasing incentives for increased savings in defined contribution plans.

However, the guarantee of the PBGC is not complete on at least two accounts. First, the guarantee applies only up to a certain maximum pension amount. Second, the PBGC as a separate legal entity from the Federal government does not explicitly benefit from any kind of financial guarantee. This lack of an explicit guarantee on behalf of the Federal government clearly makes economic sense. If the amounts at stake are simply too big, there is no way the government could uphold such a guarantee, as it would itself likely face cash-flow problems.

\section{What About Inflation Risk?}

As noted above, when thinking in terms of a simple life-cycle model allowing for price uncertainty, it is easy to show that individuals are interested in stabilizing their real consumption levels, not the nominal ones. Economically, it means that people prefer to have pension products at their hand that allow them to shelter them from inflation risk causing expected and unexpected drops in purchasing power.

To some surprise, such products are rather rare in the real world, when abstracting away from public pension systems. Most private plans do not offer indexed pension payments. Similarly, pension guarantees do not necessarily extend to the inflation risk. Again, the

\footnotetext{
${ }^{32}$ Pension plans pay the PBGC yearly insurance premia: per worker or retiree in multiemployer plans; per worker or retiree plus fraction of unfunded vested benefits in single employer plans.
} 
PBGC can serve as the best-known example as its guarantee does not extend to the indexation of benefits.

Indexation is probably one of the most frequently underestimated risks that individuals face. Particularly in times when observed inflation rates are low, people do not pay sufficient attention to the fact that inflation works through compounding exactly like interest charges do. There is obviously no simple and fast solution to the absence of adequate inflation sheltering of private pension products - otherwise the markets would offer such products. But it nonetheless raises an interesting social policy issue: in a world where a social and political consensus seem to have emerged on an ever increasing role for private pensions, should there not be a consensus to facilitate inflation-indexed pension products as the pensioners' gains from such inflation-shielding are so clear?

The pension industry itself might probably not represent the element in the financial chain that is best suited for taking on such inflation risk. But other alternatives might be at hand, be they under the form of private sector financial contracts designed to shift the risk to entities willing to absorb it for an adequate price, or be it under the form of the government offering treasury inflation protected securities that could then, in turn, be bought by pension funds to protect themselves against price fluctuations. ${ }^{33}$ Examples of inflation-indexed bonds exist (for example in the United States, the United Kingdom, Canada, or France) but overall this financial market segment remains rather small. In both cases, the coverage against the inflation risk involves a need for adequate pricing of the risk that these private or public entities take on.

\section{Concluding Comments}

The present paper started by surveying some of the key elements that one necessarily encounters when setting up and running a pension system. The most often cited one is no doubt the funding of the scheme and more precisely the PAYG or capitalization basis for the pensions. The paper illustrated the link with aggregate savings within the context of the PRA proposal and showed that aggregate savings do not necessarily increase as a result of the proposed shift towards more capitalization.

While aggregate savings are undoubtedly of a major importance to the economy, the emphasis of the paper has been a different one reflecting the view that other factors are playing an equally important role while not getting the attention they deserve. All across the globe, there seems to be a reallocation of risk towards individuals. Partly under pressure from new tighter accounting rules, employers are increasingly trying to offload private workplacerelated pension liabilities from their balance sheet by shifting risks towards governments and workers alike.

\footnotetext{
${ }^{33}$ The latter scenario would involve present and future taxpayers ultimately bearing the inflation risk.
} 
The paper emphasizes the crucial role that risk pooling under the form of real annuities plays in individual consumption planning. The paper also stresses the importance of imperfections that current workers and pensioners alike face, be it because of uncertain returns, lack of actuarial neutrality, or because of an insufficient degree of certainty that they face that the pension fund they entrusted their money to will ultimately be around or able to stand up to its obligations when they will be drawing down their assets in their old ages.

The discussed PRA proposal, though containing an option for a price-indexed pension, does not deliver on the other margins. Risk pooling is limited by its voluntary nature. It also clearly shifts both investment risk and demographic risk away from the government to those individuals who opt for this particular form of voluntary savings accounts. By doing so, the proposal reduces the economic value of the real annuity payout stream the individual will be entitled to in the future, as he will be facing a large degree of variability in pension payments depending on how his pension investment strategy pays off. The proposal does not limit potential losses, and thus income variability, to the present discounted value of a worker's payroll taxes going into the PRA. Any shortfall on the PRA side would thus be entirely borne by the individual through a reduction in the net Social Security pension through offsetting. 


\section{REFERENCES}

Belan, P., and P. Pestieau, 1999, "Privatizing Social Security: A Critical Assessment,” The Geneva Papers on Risk and Insurance, Issues and Practice, 24, pp. 114-30.

Blöndal, S., and S. Scarpetta, 1998, “The Retirement Decision in OECD Countries,” OECD Working Paper 202 (Paris: Organisation for Economic Co-operation Development).

Börsch-Supan, A., T. Boeri, and G. Tabellini, 2005, "How Would You Like to Reform Your Pension System? The Opinions of German and Italian Citizens,” in The Politics and Finance of Social Security Reform, ed. by R. Brooks and A. Razin (Cambridge University Press), (under press).

, A. Ludwig, and J. Winter, 2002, “Aging and International Capital Flows,” in Aging, Financial Markets and Monetary Policy, ed., by A. Auerbach and H. Hermann (Heidelberg: Springer).

Burtless, G., 2001, “The Rationale for Fundamental Pension Reform in Germany and the United States: An Assessment,” CESifo Working Paper 510.

Cocco, J., and P. Lopes, 2004, “Defined Benefit or Defined Contribution? An Empirical Study of Pension Choices” (London: London Business School), manuscript.

Coile, C., P. Diamond, J. Gruber, and A. Jousten, 2002, “Delays in Claiming Social Security Benefits,” Journal of Public Economics, 84 (3), pp. 357-85.

Diamond, P., and J. Mirrlees, 1978, “Social Insurance with Variable Retirement,” Journal of Public Economics 10, pp. 295-336.

, 1986, "Payroll Tax Financed Social Insurance with Variable Retirement,” Scandinavian Journal of Economics, 88, pp. 25-50.

Diamond, P., and E. Sheshinski, 1995, "Economic Aspects of Optimal Disability Benefits," Journal of Public Economics 57, pp. 1-24.

Eckstein, Z., M. Eichenbaum, and D. Peled, 1985, "Uncertain Lifetime and the Welfare Enhancing Properties of Annuity Markets and Social Security,” Journal of Public Economics 26, pp. 303-26.

Engen, E. and W. Gale, 1997, "Effects of Social Security Reform on Private and National Saving,” in Sass, S. and R. Triest, eds., "Social Security Reform: Links to Saving, Investment, and Growth,” Federal Reserve Bank of Boston, pp. 103-42.

Geanakoplos, J., O. Mitchell, and S. Zeldes, 1998, “Would a Privatized Social Security System Really Pay a Higher Rate of Return?” in Framing the Social Security Debate: Values, Politics and Economics, ed. by R. Arnold, M. Graetz, and A. Munnell (Washington: National Academy of Social Insurance). 
Gruber, J., and D. Wise, 1999, eds., "Social Security and Retirement Around the World” (NBER and Chicago: University of Chicago Press).

, and __ 2004, eds., "Social Security Programs and Retirement Around the World: Micro-Estimation” (NBER and Chicago: University of Chicago Press).

, and __, 2005, eds., "Social Security Programs and Retirement Around the World: Fiscal Implications” (NBER and Chicago: University of Chicago Press) (forthcoming).

Gustman, A., and T. Steinmeier, 2005, "Offsetting the Principal in the New Social Security Accounts,” Tax Notes, Vol. 107 (1).

Heller, P., 1998, “Rethinking Public Pension Reform Initiatives,” IMF Working Paper 98/61 (Washington: International Monetary Fund).

, 2004, “Are Governments Overextended? Assessing the Spectrum of a Government's Debts and Its Exposure to Risk,” World Economics, 5 (4), pp. 1-31.

Herbertsson, T., and J.M. Orszag, 2001, “The Costs of Early Retirement in the OECD,” Institute of Economic Studies Working Paper 01/02.

Holzmann, R., and R. Hinz, 2005, “Old Age Income Support in the $21^{\text {st }}$ Century. An International Perspective on Pension Systems and Reform” (Washington: World Bank).

Holzmann, R., R. Palacios, and A. Zviniene, 2004, “Implicit Pension Debt: Issues, Measurement and Scope in International Perspective,” World Bank, Social Protection Discussion Paper 0403 (Washington: World Bank).

International Monetary Fund, 2004, "How will Demographic Change Affect the Global Economy,” Chapter 3 of “World Economic Outlook-September 2004” (Washington: International Monetary Fund).

Jousten, A., 2001, "Life-Cycle Modeling of Bequests and Their Impact on Annuity Valuation,” Journal of Public Economics, 79 (1), pp. 149-77.

, and F. Legros, 2005, "Pensions and Savings in a Monetary Union: An Analysis of Capital Flows,” in Regional Currency Areas in Financial Globalization, ed. by

A. Cartapanis, P. Artus, and F. Legros (Cheltenham: Edward Elgar).

Kotlikoff, L.J., and Spivak, A., 1981, “The Family as an Incomplete Annuities Market,” Journal of Political Economy, 89 (2), pp. 372-91.

LaChance, M.E., and O. Mitchell, 2003, "Understanding Individual Account Guarantees” (Michigan: University of Michigan Retirement Research Center), WP-2003-035. 
Lequiller, F., 2004, "Lessons from the OECD Workshop on 'Accounting for Implicit Pension Liabilities’,” IMF mimeo, www.imf.org/external/np/sta/ueps/2004/070704.pdf

Mackenzie, G.A., 2005, “Annuity Markets and Pension Reform,” unpublished manuscript.

OECD, 2005, “Private Pensions: OECD Classification and Glossary,” (Paris: Organisation for Economic Co-operation Development).

Oksanen, H., 2004, "Public Pensions in the National Accounts and Public Finance Targets," CESifo Working Paper 1214.

PBGC, 2005, “Pension Insurance Data Book 2004” (Washington: PBGC).

Pitzer, J., 2002, “The Treatment of Pension Schemes in Macroeconomic Statistics,” Statistics Department Discussion Paper (Washington: International Monetary Fund).

Poterba, J., S. Venti, and D. Wise, 1996, “How Retirement Savings Programs Increase Savings,” Journal of Economic Perspectives, 10 (4), pp. 91-112.

Reno, V., M. Graetz, K. Apfel, J. Lavery, and C. Hill, eds., 2005, “Uncharted Waters: Paying Benefits from Individual Accounts in Federal Retirement Policy,” Study Panel Final Report, National Academy of Social Insurance (Washington).

Sheshinski, E., 2003, "Bounded Rationality and Socially Optimal Limits on Choice in a Self-Selection Model,” CESifo Working Paper 868.

Shiller, R., 2005, “The Life-Cycle Personal Accounts Proposal for Social Security: An Evaluation,” NBER Working Paper 11300.

Schokkaert E., Verhue M., and G. Pepermans, 2000, "Vlamingen Over het Pensioen Systeem,” in De toekomst van onze pensioenen, ed. by Pestieau P., Gevers L., Ginsburgh V., Schokkaert E., and B. Cantillon, Garant Leuven, pp. 55-76.

United Nations, 2005, “The World Population Prospects, The 2004 Revision, Highlights,” ESA/P/WP.193 (New York: United Nations).

Visco, I., 2006, “Longevity Risk and Financial Markets,” Banca d’Italia, mimeo.

Yermo, J., 2002, “Revised Taxonomy For Pension Plans, Pension Funds and Pension Entities” (Paris: Organisation for Economic Co-operation Development). , 2003, National Accounts and Economic Statistics, Recent Developments in Occupational Pension Plan Accounting, OECD, STD/NAES, 3 (Paris: Organisation for Economic Co-operation Development). 
Yaari, M.E., 1965, Uncertain Lifetime, Life Insurance, and the Theory of the Consumer, Review of Economic Studies 32, pp. 137-50. 